\title{
Development, Physiology and Productivity of the Common Bean Under Different Nitrogen Doses
}

\author{
João Everthon da Silva Ribeiro ${ }^{1}$, Arliston Pereira Leite ${ }^{1}$, José Eldo Costa ${ }^{1}$, Manoel Bandeira de Albuquerque ${ }^{1}$ \\ $\&$ Fábio Mielezrski ${ }^{1}$ \\ ${ }^{1}$ Universidade Federal da Paraíba, Centro de Ciências Agrárias, Areia, Paraíba, Brazil \\ Correspondence: João Everthon da Silva Ribeiro, Universidade Federal da Paraíba, Centro de Ciências Agrárias, \\ Areia, Paraíba, Brazil. Email: j.everthon@hotmail.com
}

Received: March 12, 2018

Accepted: April 10, $2018 \quad$ Online Published: May 15, 2018

doi:10.5539/jas.v10n6p171

URL: https://doi.org/10.5539/jas.v10n6p171

\begin{abstract}
Among nutrients, nitrogen is required in the greatest quantities by bean culture. The objective of this work was to evaluate growth, physiological responses and productivity of the common bean cultivar, 'IAC Imperador' under varying nitrogen doses in Brejo Paraibano. The experiment was carried out at Fazenda Experimental Chã-de-Jardim (Chã-de-Jardim Experimental Farm), of the Centro de Ciências Agrárias of the Universidade Federal da Paraíba, in the municipality of Areia, state of Paraíba. The treatments comprised 0, 50, 100, 150 and $200 \mathrm{~kg}$ of nitrogen $\mathrm{ha}^{-1}$, applied in coverage at 35 days after sowing. To assess growth, plant height, stem diameter and number of leaves were evaluated. For gas exchange, photosynthesis rate, internal $\mathrm{CO}_{2}$ concentration, transpiration, stomatal conductance, instantaneous water use efficiency and instantaneous carboxylation efficiency were evaluated. For chlorophyll " $a$ " fluorescence, minimum leaf fluorescence, maximum leaf fluorescence, variable maximum fluorescence, potential quantum efficiency of PSII (Photosystem II) and ratio $\left(\mathrm{F}_{\mathrm{v}} / \mathrm{F}_{0}\right)$ were evaluated. For the components of primary productivity, the height of insertion of the first pod, number of pods per plant and the number of grains per pod were evaluated. Nitrogen fertilization in coverage significantly affected most of the growth, gas exchange and productivity variables, with the dose of $200 \mathrm{~kg} \mathrm{ha}^{-1}$ being responsible for the highest values $(\mathrm{p}<0.05)$. Chlorophyll fluorescence showed no significant differences among the nitrogen doses. The nitrogen doses influenced the growth, gas exchange and productivity of the common bean in the region of Brejo Paraibano.
\end{abstract}

Keywords: Phaseolus vulgaris, management of fertilization, gas exchange, ecophysiology

\section{Introduction}

Beans (Phaseolus vulgaris L.) are one of the most economically important crops for Brazil (FAO, 2017), generating employment and income, and are an important source of protein for the population. The expected national production in 2017 exceeds 3.3 million tons (IBGE, 2017). However, the average productivity of $886 \mathrm{~kg}$ $\mathrm{ha}^{-1}$ (CONAB, 2017) is considered low and due mainly to the low level of technology employed (Nascente et al., 2012).

The management of fertilization is considered fundamental to achieving better grain yields (Arf et al., 2011), with nitrogen $(\mathrm{N})$ being the most influential nutrient for bean crops. This macronutrient is of great importance to the physiology of bean plants because it acts on the composition of the chlorophyll molecule by transforming photoassimilates into grain, thereby increasing productivity (Soratto et al., 2006). When evaluating fertilization with nitrogen in coverage, Crusciol et al. (2007) found productivity above $3,000 \mathrm{~kg} \mathrm{ha}^{-1}$, and obtained significant responses for nitrogen doses up to a maximum of $120 \mathrm{~kg} \mathrm{ha}^{-1}$. High doses of nitrogen can stimulate vegetative growth and cause morphological changes in plants (Marschner, 1995). Growth assessment is essential for analyzing the effects of management systems on plants by providing information on plant productivity as a function of time, which is impossible to obtain from only grain yield (Urchei et al., 2000).

Several Brazilian ecosystems are favorable for bean cultivation, including the Brazilian semi-arid region, which possesses intrinsic edaphoclimatic conditions. However, there is a lack of studies in support of making the management of nitrogen fertilization and the use of more productive genotypes feasible for achieving satisfactory yields and results for producers. 
Knowing that climatic conditions influence gas exchange in plants (Taiz et al., 2017), temperature, radiation rate and $\mathrm{CO}_{2}$ concentration can influence plant growth and production. Therefore, the study of changes is an important tool for determining the adaptation of plants to different environmental conditions since the reduced morphological development may be related to photosynthetic activity (Paiva et al., 2005).

There are many studies in the literature related to the management of different doses nitrogen fertilization for the common bean. However, the results vary depending on regional, climatic and management factors. Thus, the objective of this work was to evaluate the growth and physiological responses of the common bean (Phaseolus vulgaris) cv. IAC Imperador under different doses of nitrogen fertilization in coverage in the region of Brejo Paraibano.

\section{Method}

\subsection{Study Area and Cultivar}

The research was carried out from July to September 2017 at Fazenda Experimental Chã-de-Jardim (Chã-de-Jardim Experimental Farm) belonging to Centro de Ciências Agrárias of the Universidade Federal da Paraíba, in the municipality of Areia of the state of Paraíba (Figure 1). The predominant climate in the region is Aw', according to the classification of Peel et al. (2007), characterized as tropical, with the highest rainfall in the months of June and July. Data on rainfall, mean temperature and relative humidity during the experiment are shown in Figure 2.

The bean cultivar was used 'IAC Imperador', which possesses genetic material with determined growth (type I), semi-erect habit, and an early cycle that lasts around 70 to 75 days. The cultivar is resistant to anthracnose and Fusarium wilt (Chiorato et al., 2012).

The properties of the soil indicated $\mathrm{pH}$ in $\mathrm{H}_{2} \mathrm{O} 4.8 ; 2.40 \mathrm{mg} \mathrm{dm}^{-3}$ of $\mathrm{P} ; 28.40 \mathrm{mg} \mathrm{dm}^{-3}$ of K; $0.05 \mathrm{cmol}_{\mathrm{c}} \mathrm{dm}^{-3}$ of $\mathrm{Na}^{+} ; 5.49 \mathrm{cmol}_{\mathrm{c}} \mathrm{dm}^{-3}$ of $\mathrm{H}^{+}+\mathrm{Al}^{3+} ; 0.10 \mathrm{cmol}_{\mathrm{c}} \mathrm{dm}^{-3}$ of $\mathrm{Al}^{3+} ; 0.81 \mathrm{cmol}_{\mathrm{c}} \mathrm{dm}^{-3}$ of $\mathrm{Ca}^{2+} ; 0.30 \mathrm{cmol}_{\mathrm{c}} \mathrm{dm}^{-3} \mathrm{of} \mathrm{Mg}^{2+}$; $1.23 \mathrm{cmol}_{\mathrm{c}} \mathrm{dm}^{-3}$ of base sum; $6.72 \mathrm{cmol}_{\mathrm{c}} \mathrm{dm}^{-3}$ of effective CEC and $36.72 \mathrm{~g} \mathrm{~kg}^{-1}$ of organic matter.

The experiment was fertilized with 30 and $50 \mathrm{~kg} \mathrm{ha}^{-1}$ of $\mathrm{P}_{2} \mathrm{O}_{5}$ and $\mathrm{K}_{2} \mathrm{O}$ at planting (in the form of single superphosphate and potassium chloride, respectively). For correction of the soil, liming with $4.8 \mathrm{t} \mathrm{ha}^{-1}$ of dolomitic limestone (PRNT $=100 \%$ ), was performed a week prior to planting. Sowing was done in lines spaced $50 \mathrm{~cm}$ apart, with 12 seeds each per linear meter, in plots of $3 \times 3 \mathrm{~m}$, in order to obtain a population of approximately 240,000 plants per hectare.

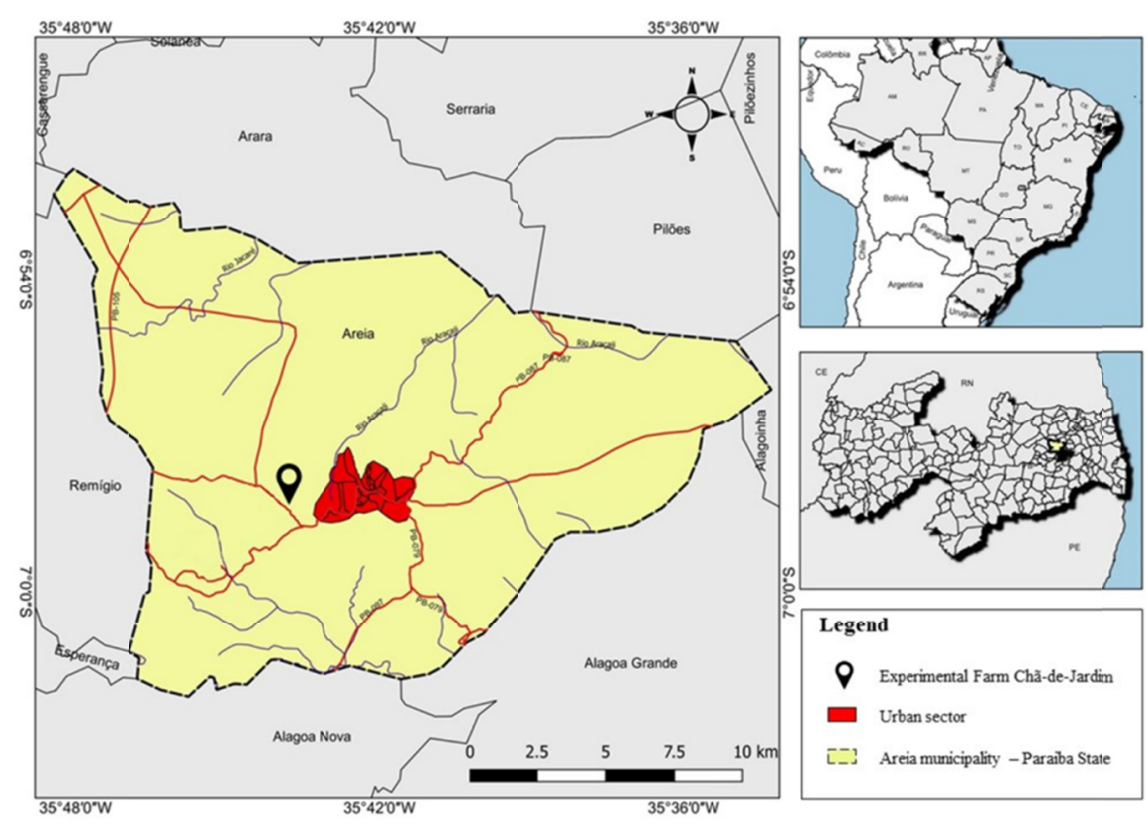

Figure 1. Geographic location of Fazenda Experimental Chã-de-Jardim, municipality of Areia, state of Paraiba, Brazil 


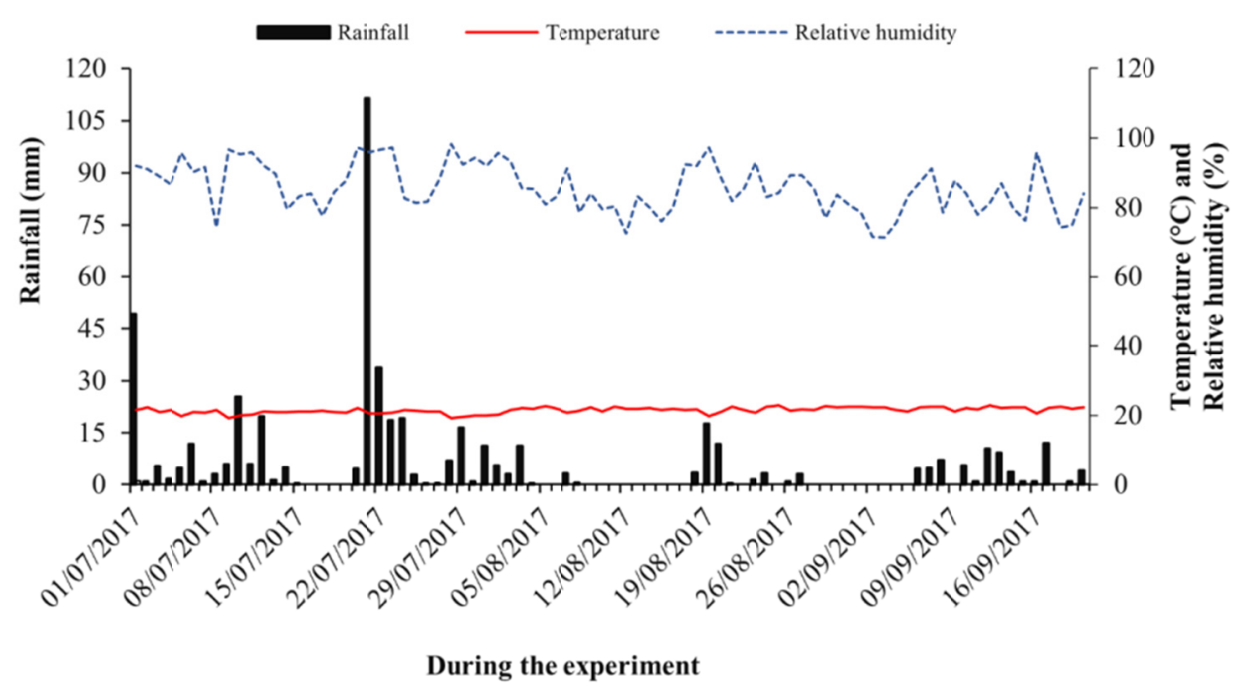

Figure 2. Rainfall $(\mathrm{mm})$, temperature $\left({ }^{\circ} \mathrm{C}\right)$ and relative humidity $(\%)$ in the period of conducting the experimente, between July and September of 2017. Obtaineds datas at the Estação Meteorológica do Centro de Ciências Agrárias, Universidade Federal da Paraíba, municipality of Areia, state of Paraiba, Brazil

\subsection{Growth}

Growth was evaluated at 45 and 60 days after sowing (DAS) by: counting the number of photosynthetically active leaves per plant $(\mathrm{NL})$; measuring plant height $(\mathrm{PH})$ (from the lap to the apical geme) in $\mathrm{cm}$ using a ruler; and measuring stem diameter (SD) in mm using a digital caliper.

\subsection{Gas Exchange}

Data on gas exchange was collected by measuring: rate of photosynthesis $(\mathrm{A})\left(\mu \mathrm{mol} \mathrm{m} \mathrm{m}^{-2} \mathrm{~s}^{-1}\right)$; internal $\mathrm{CO}_{2}$ concentration (Ci) $\left(\mu \mathrm{mol} \mathrm{m} \mathrm{m}^{-2} \mathrm{~s}^{-1}\right)$; transpiration (E) (mmol de $\left.\mathrm{H}_{2} \mathrm{O} \mathrm{m}^{-2} \mathrm{~s}^{-1}\right)$; stomatal conductance (gs) (mol m${ }^{-2}$ $\left.\mathrm{s}^{-1}\right)$; instantaneous water use efficiency (IWUE - A/E) $\left[\left(\mu \mathrm{mol} \mathrm{m} \mathrm{s}^{-2}\right) /\left(\mathrm{mmol} \mathrm{de} \mathrm{H}_{2} \mathrm{O} \mathrm{m}^{-2} \mathrm{~s}^{-1}\right)\right]$, calculated by relating liquid photosynthesis to transpiration; and the instantaneous carboxylation efficiency (ICE $-\mathrm{A} / \mathrm{Ci}$ ) $\left[\left(\mu \mathrm{mol} \mathrm{m} \mathrm{m}^{-2} \mathrm{~s}^{-1}\right) /\left(\mu \mathrm{mol} \mathrm{m} \mathrm{m}^{-2} \mathrm{~s}^{-1}\right)\right]$, from the relationship between liquid photosynthesis and internal carbon concentration. Measurements were made on healthy, unmarked and completely open leaves using a portable infrared carbon analyzer (IRGA, Licor 6400XL) under natural atmospheric conditions. Measurements were made between 10:00 $\mathrm{h}$ and 11:00 h, 60 days after sowing (DAS).

\subsection{Chlorophyll " $a$ " Fluorescence}

Chlorophyll " $a$ " fluorescence was measured and the following parameters determined: minimum fluorescence of a dark adapted leaf $\left(\mathrm{F}_{0}\right)$; maximum fluorescence of a dark adapted leaf $\left(\mathrm{F}_{\mathrm{m}}\right)$; maximum variable fluorescence $\left(\mathrm{F}_{\mathrm{v}}\right.$ $\left.=\mathrm{F}_{\mathrm{m}}-\mathrm{F}_{0}\right)$; potential quantum efficiency of PSII $\left(\mathrm{F}_{\mathrm{v}} / \mathrm{F}_{\mathrm{m}}\right)$; and the ratio $\mathrm{F}_{\mathrm{v}} / \mathrm{F}_{0}$. Measurements of chlorophyll fluorescence were performed on intact leaves attached to plants previously adapted to dark for 30 minutes, beginning at 10 hours, at 60 days post sowing, using a fluorimeter [OS-30p + (Optisci)].

\subsection{Productivity}

Harvesting was performed with the plants at stage R9—-pod maturity—on 20 September 2017. At the time of harvest, evaluations were made on the components of primary productivity. The height of insertion of the first pod (HIFP) was measured with a ruler from the lap of the plant until the insertion of the first pod. The number of pods per plant (NPP) was determined by counting the total number of pods and dividing the total by the total number of plants. The number of grains per pod (NGP) was obtained by dividing the total number of grains by the total number of pods.

\subsection{Experimental Design}

A randomized block design with five treatments and four replicates was used. Treatments consisted of the application of increasing dosages of nitrogen in coverage, 35 days after sowing. Urea was used as a source of nitrogen. Thus, treatments were: T1 (control, $\left.0 \mathrm{~kg} \mathrm{ha}^{-1}\right), \mathrm{T} 2\left(50 \mathrm{~kg} \mathrm{ha}^{-1}\right), \mathrm{T} 3\left(100 \mathrm{~kg} \mathrm{ha}^{-1}\right), \mathrm{T} 4\left(150 \mathrm{~kg} \mathrm{ha}^{-1}\right)$ and 
T5 $\left(200 \mathrm{~kg} \mathrm{ha}^{-1}\right)$. The plots had a total area of $9.0 \mathrm{~m}^{2}$ and a useful area of $6.0 \mathrm{~m}^{2}$, in which five plants were chosen, at random from three central lines of each plot, so that they could be evaluated.

The data were submitted to analysis of variance, according to the design adopted. In the study of the effects of $\mathrm{N}$ doses, data were submitted to regression analysis, with adjustment of representative curves, according to the evaluated characteristics (Soares et al., 2016).

\section{Results and Discussion}

\subsection{Growth Analyses}

Table 1 provides F-test results that show that nitrogen fertilization did not affect plant height, but significantly affected diameter and the number of leaves. The CVs of all of the variables analyzed were low. It should be emphasized that the experiment was carried out in the field.

Figure $3 \mathrm{~A}$ shows mean plant height at 45 and 60 days after sowing. Height did not differ significantly among nitrogen doses, but maximum heights were obtained at doses of 0 and $200 \mathrm{~kg} \mathrm{~h}^{-1}$ for both evaluation periods, with it being $8.3 \mathrm{~cm}$ at 45 days and $18.4 \mathrm{~cm}$ at 60 days. The dose of $100 \mathrm{~kg} \mathrm{ha}^{-1}$ produced the shortest height for both evaluation periods.

These results are the opposite of those reported by Biscaro et al. (2012), who found a growth response up to the dose of $125 \mathrm{~kg} \mathrm{ha}^{-1}$, and for Cunha et al. (2013) and Viana et al. (2013), where they obtained increases in growth due to the application of up to 136 and $108 \mathrm{~kg} \mathrm{ha}^{-1}$, respectively. However, the results of Valderrama et al. (2012), not found an effect of nitrogen fertilization on plant height, are similar to those of the present study. These differing results may be related to different edaphoclimatic conditions where the experiments took place. According to the edaphoclimatic conditions observed during the present experiment (Figure 2), accumulated value $(495.8 \mathrm{~mm})$ was higher than the water requirement of the crop, which ranged from 300 to $400 \mathrm{~mm}$ (Moreira et al., 2003). Souza et al. (2013) attributed these differences specifically to soil fertility levels and to the production systems adopted by the authors, in addition to irrigation.

Studying different bean genotypes under varying doses of nitrogen fertilizer, Sousa et al. (2012) found higher growth with the use of $80 \mathrm{~kg} \mathrm{ha}^{-1}$, and a constant growth until the dose of $150 \mathrm{~kg} \mathrm{ha}^{-1}$, with doses higher than this causing a negative effect on growth. Evaluating different doses of fertilization in different salinities, Sousa et al. (2013) did not find differences between the doses of nitrogen applied up to $190 \%$ of the recommended dose for bean crops. Similarly, working with sources and doses of N, on the surface and incorporated, Cunha et al. (2013) also observed an increase in bean height with nitrogen supply.

Studying organomineral fertilization, Nakayama et al. (2013) observed linear growth as a function of the application of nitrogen up to $250 \mathrm{~kg} \mathrm{ha}^{-1}$. These data are similar to those found by Salgado et al. (2012), who evaluated different bean cultivars in nitrogen poor and rich soils and found that growth was better in soils with high nitrogen concentrations.

Bean plant height did not respond well to fertilization even though it was expected that the increased availability of the nutrient would lead to greater absorption and height growth since adequate doses of nitrogen are associated with high photosynthetic activity and, consequently, vigorous vegetative growth (Souza et al., 2014). Nitrogen uptake and crop use are strongly influenced by meteorological conditions, so it is important to discuss agronomic characteristics in relation to precipitation, such as low soil water reserves and/or low precipitation, since these factors can substantially reduce nitrogen uptake, particularly immediately after fertilization (Vleugelsa et al., 2017), which indeed occured in the present study.

The studied bean 'IAC imperador', which is adapted to the region, may have developed a capacity for plasticity and translocated nutrients from other plant sites and invested in growth. This factor could lead to a reduction in other aspects of the plant, such as productivity.

The mean diameter of bean plants responded positively to the doses of nitrogen, mainly at 60 days after sowing. The dose of $200 \mathrm{~kg} \mathrm{ha}^{-1}$ promoted the greatest growth in stem diameter, with an increase of $5 \%$ and $16 \%$ relative to the control treatment at 45 and 60 days post-sowing, respectively (Figure 3B). These data are similar to those found by Nakayama et al. (2013), who obtained linearly increasing values in diameter using nitrogen fertilizer up to a dose of $250 \mathrm{~kg} \mathrm{ha}^{-1}$. On the other hand, Salgado et al. (2012) and Sousa et al. (2013) did not find significant difference for stem diameter in situations of low and high availability of nitrogen in the soil, but confirm that differences can occur depending on the conditions of the growth environment or the use of different cultivars.

Studying nitrogen fertilization of up to $150 \mathrm{~kg} \mathrm{ha}^{-1}$ at different times, Vleugelsa et al. (2017) did not find differences in plant diameter among applied doses. This may have been due to the fact that nitrogen is a very 
volatile nutrient in the soil and its value changes rapidly depending on, most importantly for bean crops, soil and climate conditions (Rodriguez et al., 2016; Yuan et al., 2017).

Increased nitrogen dosage produced a greater number of photosynthetically active leaves on the bean plants, with a greater increase at 60 days post-sowing, ranging from 8.6 leaves per control plant to 11.3 leaves per plant at the maximum dose used (Figure 3C). These data differ from those of Sousa et al. (2013), who did not find significant differences for the number of leaves while studying saline water and different doses of nitrogen up to the maximum recommended dose for the crop.

Nitrogen is fundamental for good leaf development and a greater number of leaves since it acts on plant metabolism favoring the physiological processes of growth, distance between nodes and cell division. Thus, the more available nitrogen the greater the quantity of leaves produced up to a limit considered optimal (Kurtz et al., 2012).

Table 1. F test for plant height; stem diameter; and number of leaves (NL) of cultivated beans under different doses of nitrogen

\begin{tabular}{llll}
\hline \multirow{2}{*}{ Source of Variation } & \multicolumn{3}{c}{ F Test } \\
\cline { 2 - 4 } & Height & Diameter & NL \\
\hline N rates & $\mathrm{ns}$ & $* *$ & $* *$ \\
Quadratic Reg. & $\mathrm{ns}$ & $* *$ & $*$ \\
Block & $\mathrm{ns}$ & $\mathrm{ns}$ & $*$ \\
C.V. $(\%)$ & 5.35 & 12.34 & 17.21 \\
\hline
\end{tabular}

Note. $\mathrm{ns},{ }^{* *},{ }^{*}$ respectively, not significant, significant at $\mathrm{p}<0.01$ and $\mathrm{p}<0.05$, by F-test.
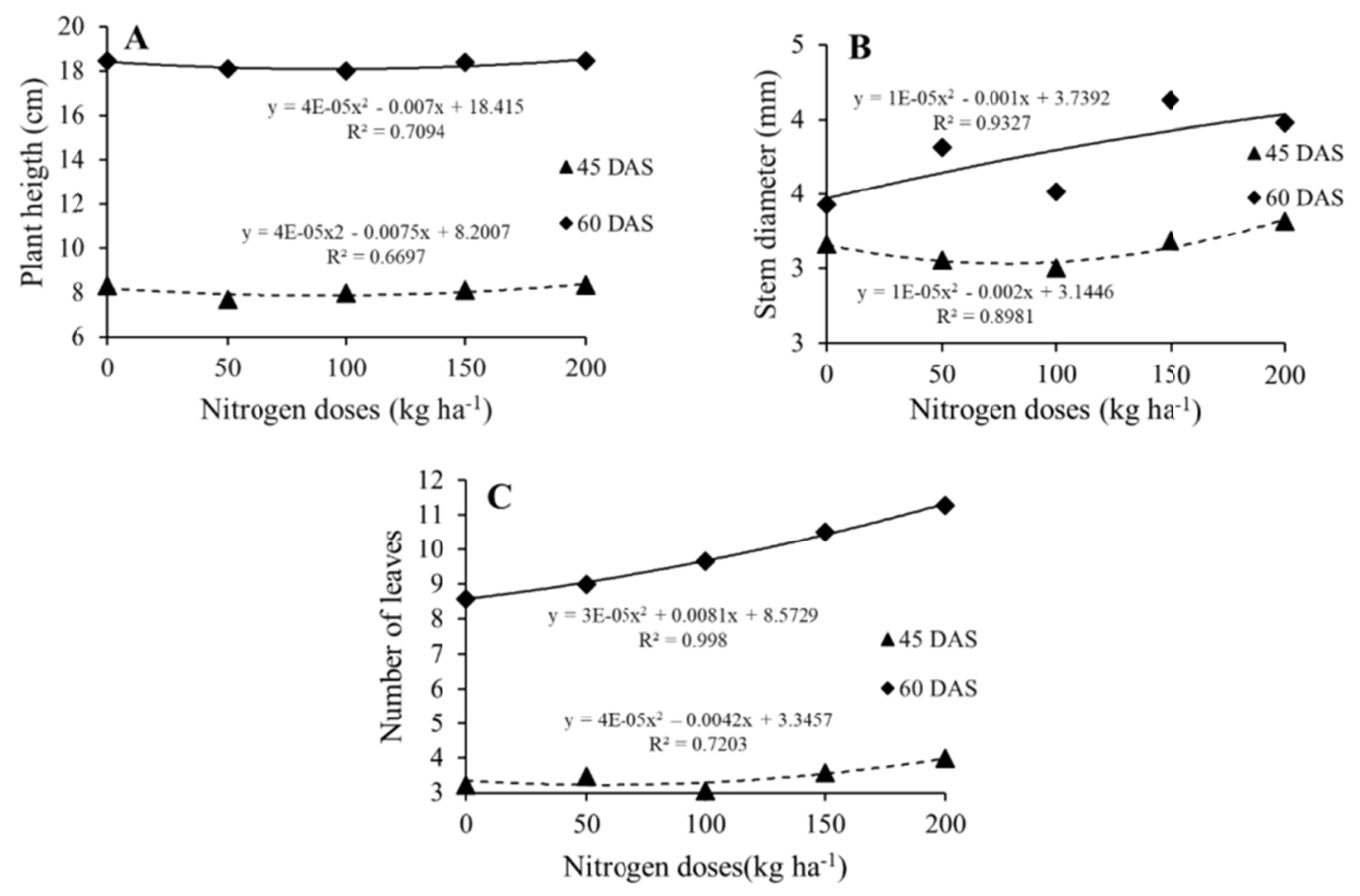

Figure 3. Plant height (A), stem diameter (B) and number of leaves (C) of cultivated beans under different doses of nitrogen

\subsection{Gas Exchange}

The F-test results show that nitrogen fertilization significantly affected the rate of photosynthesis, transpiration, internal $\mathrm{CO}_{2}$ concentration, instantaneous water use efficiency and instantaneous carboxylation efficiency $(\mathrm{p}<$ 
0.05), but not stomatal conductance (Table 2). Evaluating the effect of nitrogen fertilization on growth and gas exchange of bean plants, Soares et al. (2013), found a significant effect of nitrogen doses only for transpiration.

Figure 4 provides the mean values for the physiological responses of beans to the effects of $\mathrm{N}$ doses, specifically for photosynthetic rate (A), internal $\mathrm{CO}_{2}$ concentration (Ci), transpiration (E), stomatal conductance (gs), instantaneous water use efficiency (IWUE) and instantaneous carboxylation efficiency (ICE).

Regarding gas exchange, the values for photosynthetic rate (A) exhibited an increasing linear response to the effect of the doses of $\mathrm{N}$ and, according to the regression equation, the values range from $15.552 \mu \mathrm{mol} \mathrm{m}^{-2} \mathrm{~s}^{-1}$ (control, $0 \mathrm{~kg}$ of nitrogen ha ${ }^{-1}$ ) to $17.891 \mu \mathrm{mol} \mathrm{m}^{-2} \mathrm{~s}^{-1}\left(200 \mathrm{~kg}^{-1}\right.$ of nitrogen ha ${ }^{-1}$ ) (Figure 4A). The dose of $200 \mathrm{~kg}$ of nitrogen $\mathrm{ha}^{-1}$ had the highest values of photosynthetic rate, which may be related to there being a sufficient amount of nitrogen since the nutritional state of plants influences photosynthesis. According to Taiz et al. (2017), the deficiency of some nutrients, such as nitrogen and magnesium, in the soil causes chlorosis in the leaves, which interferes with the process of photosynthesis. According to Larcher (2004), the highest photosynthetic rates are achieved through fertilization.

The results for transpiration (E) followed the same trend of stomatal conductance with a linear response to the effect of $\mathrm{N}$ doses, with values varying between $2.926 \mathrm{mmol} \mathrm{m}^{-2} \mathrm{~s}^{-1}$ (control, $0 \mathrm{~kg}$ of nitrogen ha ${ }^{-1}$ ) and 4.010 $\mathrm{mmol} \mathrm{m} \mathrm{m}^{-2} \mathrm{~s}^{-1}$ (200 kg of nitrogen ha-1) (Figure 4B). The elevation of leaf transpiration rate not only increases water flow in the xylem, but also raises the concentration of cytokinin synthesized in the roots, which is an important mechanism for delaying leaf senescence, as evidenced in the present study (Larcher, 2004; Marschner, 1995; Soares et al., 2013; Taiz et al., 2017).

The internal carbon concentration $(\mathrm{Ci})$ exhibited an increasing linear response to the effect of the doses of $\mathrm{N}$ and, according to the regression equation, increased the most with the dose of $200 \mathrm{~kg}$ of nitrogen ha ${ }^{-1}$ (Figure 4C). The internal carbon values varied between $188.72 \mu \mathrm{mol} \mathrm{m}^{-2} \mathrm{~s}^{-1}$ (control, $0 \mathrm{~kg}$ of nitrogen ha ${ }^{-1}$ ) and $534.19 \mu \mathrm{mol}$ $\mathrm{m}^{-2} \mathrm{~s}^{-1}\left(200 \mathrm{~kg}\right.$ of nitrogen ha $\left.{ }^{-1}\right)$. Ferraz et al. (2012) analyzed gas exchange of cultivated beans in the field in the semi-arid region of Northeast Brazil, and found no significant responses to the different doses, with the most expressive results being 277.0 and $289.6 \mu \mathrm{mol} \mathrm{m}^{-2} \mathrm{~s}^{-1}$. Evaluating the effects of nitrogen on gas exchange of the common bean, Anjos et al. (2014) found no significant effect of the different doses on internal carbon concentration.

Stomatal conductance (gs) exhibited a linear response among doses, with the lowest values being for the control $\left(0 \mathrm{~kg}\right.$ of nitrogen ha $\left.\mathrm{a}^{-1}\right)$, which had values varying between $0.157 \mathrm{~mol} \mathrm{~m}^{-2} \mathrm{~s}^{-1}$ (control) and $0.264 \mathrm{~mol} \mathrm{~m}^{-2} \mathrm{~s}^{-1}(200$ $\mathrm{kg}$ of nitrogen $\mathrm{ha}^{-1}$ ). This response may be related to a high degree of closure of the stomata at the lowest $\mathrm{N}$ doses in order to void losses to the water conduction system. Nitrogen is a nutrient involved in protoplasmic processes, enzymatic reactions and photosynthesis, causing an osmotic gradient that allows the movement of water, thereby regulating the opening and closing of stomata (Epstein \& Bloom, 2006; Silva et al., 2013).

Regarding instantaneous water use efficiency (IWUE), a reduction of $28 \%$ was observed between the highest value of $102.50\left[\left(\mu \mathrm{mol} \mathrm{m}^{-2} \mathrm{~s}^{-1}\right)\left(\mathrm{mmol} \mathrm{m}^{-2} \mathrm{~s}^{-1}\right)^{-1}\right]$ for the 200-dose $\mathrm{kg}$ of nitrogen ha ${ }^{-1}$, and the lowest value of $84.75\left[\left(\mu \mathrm{mol} \mathrm{m}^{-2} \mathrm{~s}^{-1}\right)\left(\mathrm{mmol} \mathrm{m}^{-2} \mathrm{~s}^{-1}\right)^{-1}\right]$ for the control (Figure 4E). The increase in IWUE for the 100-dose $\mathrm{kg}$ of nitrogen $\mathrm{ha}^{-1}$ may be associated with the already established benefits that this dose provides to gas exchange in bean plants, which provides better development of the photosynthetic process. This parameter is determined by the relationship between the rate of photosynthesis and the rate of transpiration $(\mathrm{A} / \mathrm{E})$, in which the values measured relate to the amount of carbon the plant receives for each unit of water it loses (Jaimez et al., 2005).

The instantaneous carboxylation efficiency (ICE), calculated by ratio $\mathrm{A} / \mathrm{Ci}$, differed among the different doses. Plants that received the dose of $200 \mathrm{~kg}$ of nitrogen $\mathrm{ha}^{-1}$ had the highest instantaneous carboxylation efficiency, with $\left.0.560\left[\left(\mu \mathrm{mol} \mathrm{m} \mathrm{m}^{-2} \mathrm{~s}^{-1}\right)(\mu \mathrm{mol} \mathrm{mol})^{-1}\right)^{-1}\right]$ (Figure $\left.4 \mathrm{~F}\right)$. The instantaneous carboxylation efficiency (ICE) obtained by Machado et al. (2005) bears little resemblance to the internal $\mathrm{CO}_{2}$ and the carbon dioxide assimilation rate. Some authors, such as Silva (2012), have found high values for internal $\mathrm{CO}_{2}$ concentration, associated with increased stomatal conductance, indicating an increase in the instantaneous carboxylation efficiency. Similar results were found in the present work, with ICE values varying among the doses of $\mathrm{N}$ applied (Figure 4F). Evaluating the effect of nitrogen fertilization on three bean-cultivars, Ferraz et al. (2012) recorded ICE values ranging from 0.03 to $0.08\left[\left(\mu \mathrm{mol} \mathrm{m}^{-2} \mathrm{~s}^{-1}\right)\left(\mu \mathrm{mol} \mathrm{mol}^{-1}\right)^{-1}\right]$. 
Table 2. $\mathrm{F}$ test for rate of photosynthesis (A); transpiration (E); internal $\mathrm{CO}_{2}$ concentration (Ci); stomatal conductance (gs); instantaneous water use efficiency (IWUE); and the instantaneous carboxylation efficiency (ICE) of cultivated beans under different doses of nitrogen

\begin{tabular}{lllllll}
\hline \multirow{2}{*}{ Source of Variation } & \multicolumn{7}{c}{ F Test } \\
\cline { 2 - 7 } & $\mathbf{A}$ & $\mathbf{E}$ & $\mathbf{C i}$ & $\mathbf{g s}$ & $\mathbf{I W U E}$ & ICE \\
\hline N rates & $* *$ & $* *$ & $* *$ & $\mathrm{~ns}$ & $* *$ & $* *$ \\
Linear Reg. & $* *$ & $* *$ & $* *$ & $*$ & $* *$ & $* *$ \\
Block & $\mathrm{ns}$ & $\mathrm{ns}$ & $*$ & $\mathrm{~ns}$ & $\mathrm{~ns}$ & $*$ \\
C.V. $(\%)$ & 6.32 & 15.49 & 15.01 & 16.07 & 3.70 & 22.02 \\
\hline
\end{tabular}

Note. $\mathrm{ns},{ }^{* *},{ }^{*}$ respectively, not significant, significant at $\mathrm{p}<0.01$ and $\mathrm{p}<0.05$, by F-test.
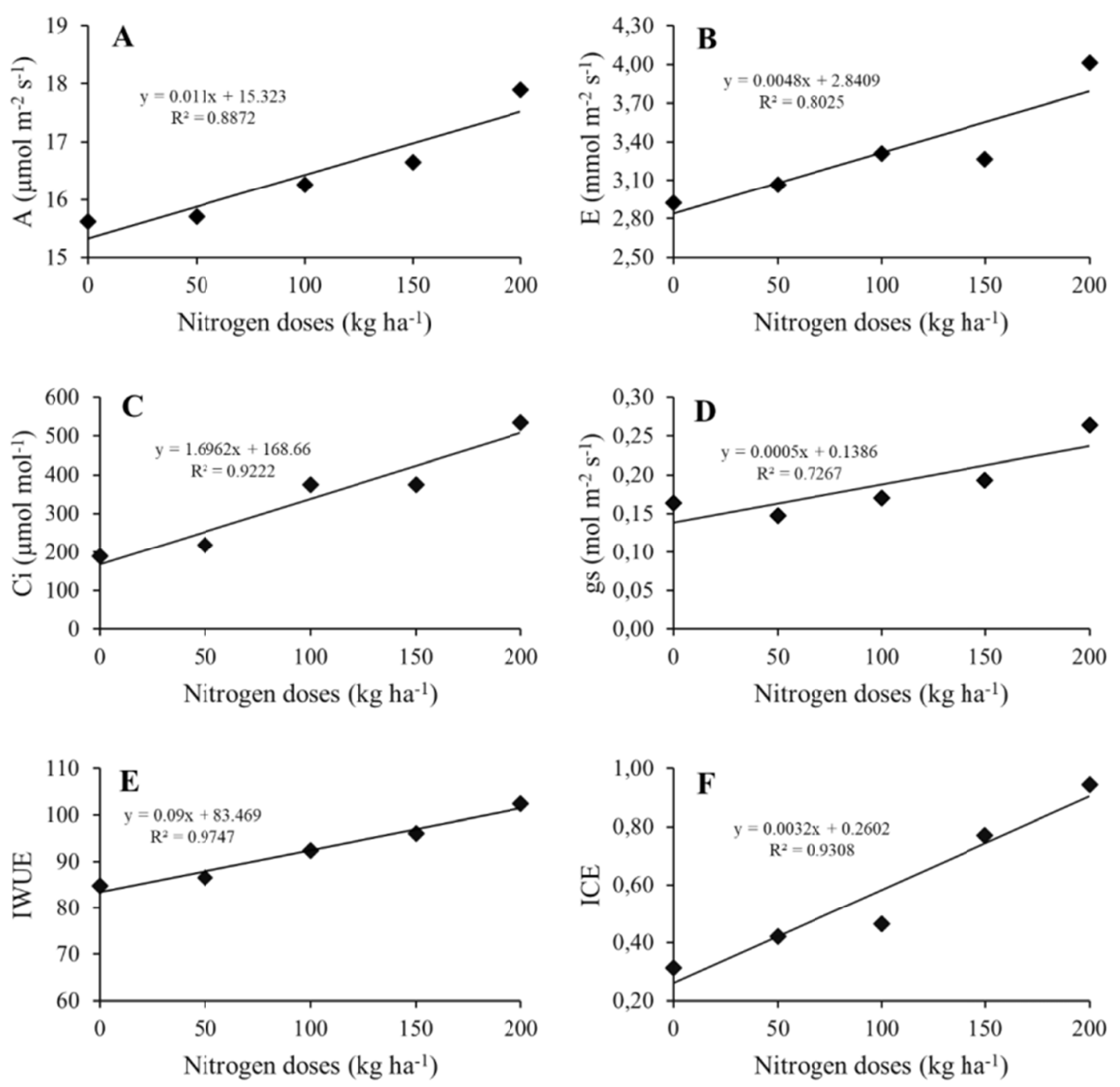

Figure 4. Means of rate of photosynthesis (A); transpiration (B); internal $\mathrm{CO}_{2}$ concentration (C); stomatal conductance (D); instantaneous water use efficiency (E); and the instantaneous carboxylation efficiency (F) of cultivated beans under different doses of nitrogen

\subsection{Chlorophyll " $a$ " Fluorescence}

Table 3 presents the results of the analysis of variance of minimum fluorescence $\left(\mathrm{F}_{0}\right)$, maximum fluorescence $\left(F_{m}\right)$, variable fluorescence $\left(F_{v}=F_{m}-F_{0}\right)$, potential quantum efficiency of PSII $\left(F_{v} / F_{m}\right)$ and ratio $F_{v} / F_{0}$ in bean plants under different doses of nitrogen (Table 3). 
In relation to chlorophyll fluorescence, no significant differences were observed among doses applied and the analyzed variables (Table 3). The doses of nitrogen applied to the bean plants did not significantly interfere with minimum fluorescence $\left(\mathrm{F}_{0}\right)$, indicating all reaction centers were open (Figure 5A). According to previous experiments (Baker \& Rosenqvst, 2004; Konrad et al., 2005; Suassuna et al., 2010), maximum fluorescence $\left(\mathrm{F}_{\mathrm{m}}\right)$ represents the maximum intensity of fluorescence, when practically all the quinone is reduced and the reaction centers reach their maximum capacity of photochemical reactions. In the case of the present study, the doses of nitrogen applied did not interfere with the reduction of quinone. Maximum variable fluorescence $\left(\mathrm{F}_{\mathrm{v}}\right)$, potential quantum efficiency of PSII $\left(\mathrm{F}_{\mathrm{v}} / \mathrm{F}_{\mathrm{m}}\right)$ and the ratio between maximum variable fluorescence and minimum fluorescence $\left(\mathrm{F}_{\mathrm{v}} / \mathrm{F}_{0}\right)$ also did not differ significantly among doses (Table 3 and Figure 5).

There have been other studies relating fertilization to fluorescence efficiency in beans. Studying different irrigation levels and fertilization of the eggplant, Silva et al. (2014) found similar values of $F_{m}$, where increased irrigation depth and nitrogen doses did not interfere with $\mathrm{F}_{\mathrm{m}}$. Therefore, in the present study (Figure 5B), the highest values of $\mathrm{F}_{\mathrm{m}}$ found, although not significant, may be related to the availability of water during the conduction of the experiment being favorable for the development of the crop (495.8 $\mathrm{mm}$ ), thus showing that it did not cause deficiency in quinone A (QA) photoreduction and the flow of electrons between photosystems (Tatagiba et al., 2014).

All of the values for potential quantum efficiency of PSII were greater than 0.75 electrons quantum ${ }^{-1}$ (Figure 5D), indicating that the photosynthetic apparatus is intact and performing all its functions. Previous works carried out with stress from fertilization and irrigation levels have verified that this is the threshold for a good response of plants to photosynthetic potential with no damage being caused (Reis \& Campostrini 2008; Santos et al., 2010; Suassuna et al., 2010).

The ratio $\mathrm{F}_{\mathrm{v}} / \mathrm{F}_{0}$ is usually used in studies to evaluate different factors in several species, among them fertilization, shading and water stress. When studying the effects of salinity and fertilization on fluorescence parameters of $P$. vulgaris, Zanandrea et al. (2006) observed a maximum value of 4.578 electrons quantum ${ }^{-1}$ when $80 \mathrm{mmol} \mathrm{L}^{-1}$ of $\mathrm{NaCl}$ was applied. Studying gas exchange and chlorophyll fluorescence in six legume cultivars under aluminum stress, Konrad et al. (2005) found that the Fv/F0 ratio did not differ significantly among the six cultivars evaluated. In view of this, it can be seen that the type and dose of nitrogen can affect the physiological behavior of plants, but soil nitrogen my have been sufficient to supply the minimum fluorescence needs of the bean in this experiment (Figure 5E).

Table 3. $\mathrm{F}$ test for minimum fluorescence $\left(\mathrm{F}_{0}\right)$; maximum fluorescence $\left(\mathrm{F}_{\mathrm{m}}\right)$; variable maximum fluorescence $\left(\mathrm{F}_{\mathrm{v}}\right)$; potential quantum efficiency of PSII $\left(\mathrm{F}_{\mathrm{v}} / \mathrm{F}_{\mathrm{m}}\right)$; and the ratio $\left(\mathrm{F}_{\mathrm{v}} / \mathrm{F}_{0}\right)$ of cultivated beans under different doses of nitrogen

\begin{tabular}{llllll}
\hline \multirow{2}{*}{ Source of Variation } & \multicolumn{5}{c}{$\mathbf{F}$ Test } \\
\cline { 2 - 6 } & $\mathbf{F}_{\mathbf{0}}$ & $\mathbf{F}_{\mathbf{m}}$ & $\mathbf{F}_{\mathbf{v}}$ & $\mathbf{F}_{\mathbf{v}} / \mathbf{F}_{\mathbf{m}}$ & $\mathbf{F}_{\mathbf{0}} / \mathbf{F}_{\mathbf{v}}$ \\
\hline N rates & $\mathrm{ns}$ & $\mathrm{ns}$ & $\mathrm{ns}$ & $\mathrm{ns}$ & $\mathrm{ns}$ \\
Quadratic Reg. & $\mathrm{ns}$ & $\mathrm{ns}$ & $\mathrm{ns}$ & $\mathrm{ns}$ & $\mathrm{ns}$ \\
Block & $\mathrm{ns}$ & $\mathrm{ns}$ & $\mathrm{ns}$ & $\mathrm{ns}$ & $\mathrm{ns}$ \\
C.V. $(\%)$ & 9.38 & 7.65 & 10.00 & 4.31 & 13.63 \\
\hline Note. & r &
\end{tabular}

Note. $\mathrm{ns},{ }^{* *},{ }^{*}$ respectively, not significant, significant at $\mathrm{p}<0.01$ and $\mathrm{p}<0.05$, by F-test. 

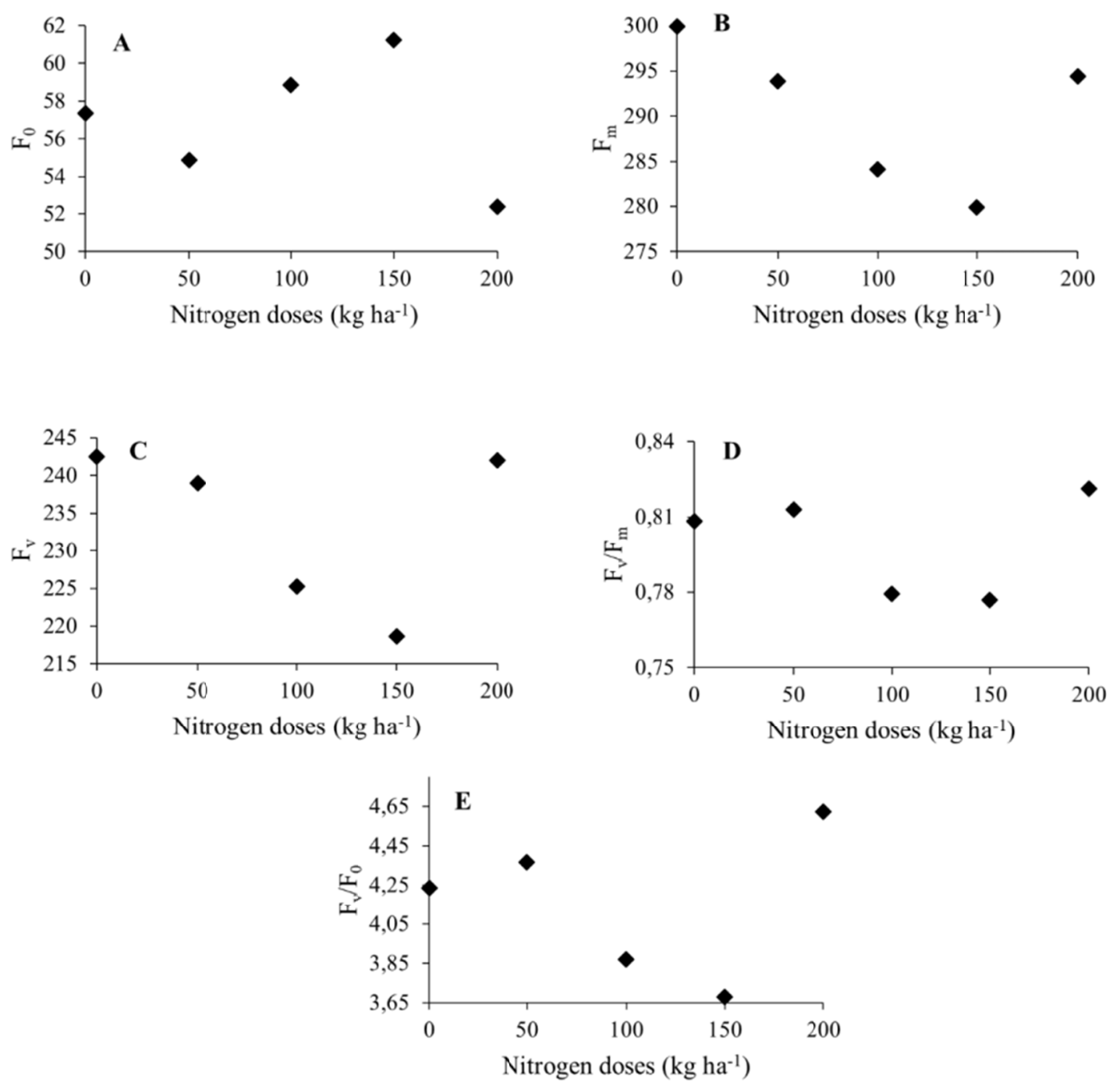

Figure 5. Minimum fluorescence $\left(\mathrm{F}_{0}\right)(\mathrm{A})$; maximum fluorescence $\left(\mathrm{F}_{\mathrm{m}}\right)(\mathrm{B})$; variable maximum fluorescence $\left(\mathrm{F}_{\mathrm{v}}\right)$ (C); potential quantum efficiency of PSII $\left(\mathrm{F}_{\mathrm{v}} / \mathrm{F}_{\mathrm{m}}\right)(\mathrm{D})$; and the ratio $\left(\mathrm{F}_{\mathrm{v}} / \mathrm{F}_{0}\right)(\mathrm{E})$ of cultivated beans under different doses of nitrogen

\subsection{Components of Primary Productivity}

Table 4 provides the F-test results for the productivity components. The number of grains per pod (NGP) and the number of pods per plant (NPP) were found to be influenced significantly by the different doses of nitrogen ( $<<$ 0.01) (Table 4). The insertion height of the first pod (HIFP) did not exhibit significantly different responses among the different nitrogen doses (Table 4). All these variables exhibited significant linear responses as a function of the different doses of $\mathrm{N}(\mathrm{p}<0.05)$ (Table 4$)$.

The insertion height of the first bean pod ranged from $12.9 \mathrm{~cm}$ (control, $0 \mathrm{~kg}$ of nitrogen ha $\left.{ }^{-1}\right)$ to $15.2 \mathrm{~cm}(200 \mathrm{~kg}$ of nitrogen $\mathrm{ha}^{-1}$ ) (Figure 6A). Insertion height of the first pod is an important characteristic at the time of harvest because plants with upright and lower positioning obtain maximum efficiency during this process (Mendes et al., 2009). Oliveira et al. (2014) emphasized that AIPV values greater than $12 \mathrm{~cm}$ should be considered acceptable because they facilitate mechanized harvesting. Therefore, all $\mathrm{N}$ doses applied to bean plants in this study presented satisfactory results for the insertion of the first pod.

According to Portes (1996), bean plants with good nutritional status produce more flowers and, consequently, more pods per plant. Therefore, the different doses of $\mathrm{N}$ used in the present study resulted in an increase in the number of pods, with values ranging from 3.25 (control, $0 \mathrm{~kg}$ of nitrogen ha $\left.\mathrm{h}^{-1}\right)$ to $5.20\left(200 \mathrm{~kg}\right.$ of nitrogen ha $\left.{ }^{-1}\right)$ (Figure 6B). The mean number of pods per plant was similar to that found by Binotti et al. (2010), and Flores et 
al. (2014). Binotti et al. (2014) did not observe a significant effect on the number of pods per plant when evaluating different nitrogen doses in the coverage,

For the number of grains per pod, the values were found to increase as a function of the different doses of $\mathrm{N}$, varying from 3.0 (control, $0 \mathrm{~kg}$ of nitrogen ha ${ }^{-1}$ ) to $4.3\left(200 \mathrm{~kg}_{\text {of nitrogen ha }}{ }^{-1}\right.$ ) (Figure 6C). Similar results were found by Arf et al. (2011), who reported a mean of 4.13 grains per pod for the Pérola cultivar. For the 'Aporé' cultivar, Silva and Silveira (2000) recorded higher productivity than the present study, with approximately 5.05 grins per pod. In their studies with nitrogen fertilization of beans, Bernardes et al. (2015), and Cardoso (2011) found no significant responses in the number of grains per pod.

Table 4. F test for height of insertion of the first pod (HIFP); number of pods per plant (NPP); and the number of grains per pod (NGP) (C) of cultivated beans under different doses of nitrogen

\begin{tabular}{llll}
\hline \multirow{2}{*}{ Source of Variation } & \multicolumn{2}{c}{ F Test } \\
\cline { 2 - 4 } & HIFP & NPP & NGP \\
\hline N rates & $\mathrm{ns}$ & $* *$ & $* *$ \\
Linear Reg. & $*$ & $* *$ & $\mathrm{~ns}$ \\
Block & $\mathrm{ns}$ & $\mathrm{ns}$ & 4.33 \\
C.V. $(\%)$ & 14.70 & 14.70 & \\
\hline
\end{tabular}

Note. $\mathrm{ns},{ }^{* *},{ }^{*}$ respectively, not significant, significant at $\mathrm{p}<0.01$ and $\mathrm{p}<0.05$, by F-test.
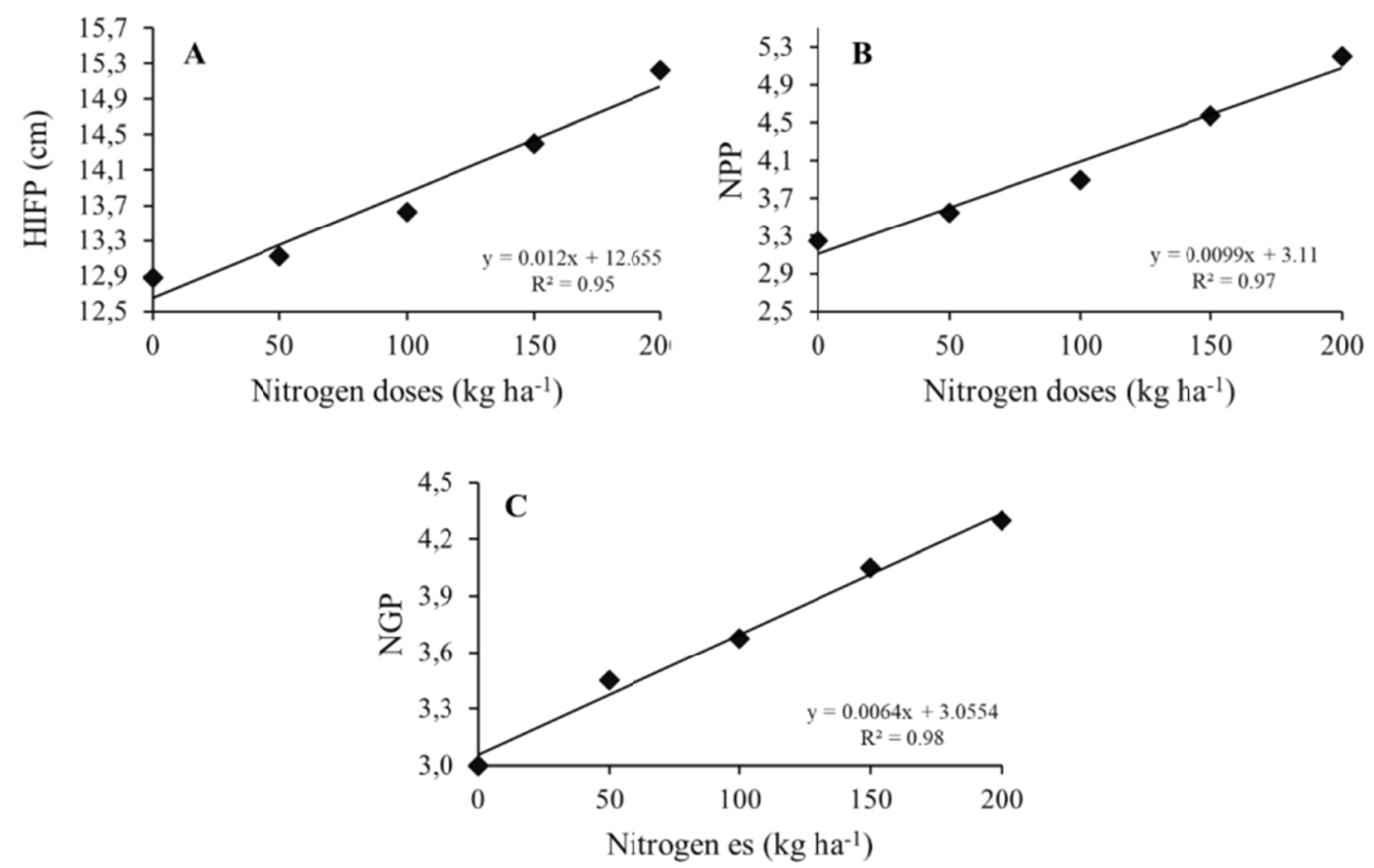

Figure 6. Height of insertion of the first pod (HIFP) (A); number of pods per plant (NPP) (B); and the number of grains per pod (NGP) (C) of cultivated beans under different doses of nitrogen

\section{Conclusion}

Nitrogen doses of up to $200 \mathrm{~kg} \mathrm{~N} \mathrm{ha}^{-1}$ were not significant for height, but there were significant differences in the number of leaves and stem diameter. With the exception of stomatal conductance, gas exchange was influenced by different doses of nitrogen, with the dose of $200 \mathrm{~kg} \mathrm{~N} \mathrm{ha}^{-1}$ having the most efficient response. Fluorescence did not change with increasing nitrogen dose, however, it can be stated that the evaluated plants exhibited a rate of photosynthetic efficiency above the culture mean. The number of grains per pod and the number of pods per plant were influenced by the nitrogen doses, with the highest average values being for the dose of $200 \mathrm{~kg} \mathrm{~N} \mathrm{ha}^{-1}$. 


\section{References}

Anjos, D. N., Vasconcelos, R. C., Mendes, H. T. A., Cangussu, A. C. V., \& Arf, M. V. (2014). Trocas gasosas em plantas de feijoeiro submetidas a fitorreguladores. NPK e micronutrientes. Enciclopédia Biofesra, 10, 1796-1802.

Arf, M. V., Buzetti, S., Arf, O., Kappes, C., Ferreira, J. P., Gitti, D. C., \& Yamamoto, C. J. T. (2011). Fontes e épocas de aplicação de nitrogênio em feijoeiro de inverno sob sistema plantio direto. Pesquisa Agropecuária Tropical, 41, 430-438. https://doi.org/10.5216/pat.v41i3.9706

Baker, N. R., \& Rosenqvst, E. (2004). Aplication of chlorophyll fluorescence can improve crop production strategies: An examination of future possibilities. Journal of Experimental Botany, 55, 1607-1621. https://doi.org/10.1093/jxb/erh196

Bernardes, T. G., Silveira, P. M., Carvalho, M. T. M., Madari, B. E., \& Carvalho, M. C. S. (2015). Produtividade do feijoeiro irrigado em razão de fontes de adubo nitrogenado estabilizado e de liberação controlada. Revista Ceres, 62, 507-509. https://doi.org/10.1590/0034-737X201562060015

Binotti, F. F. S., Arf, O., Cardoso, E. D., Sá, M. E., \& Buzetti, S. (2014). Manejo do nitrogênio em cobertura do feijoeiro de inverno no sistema plantio direto. Revista de Agricultura Neotropical, 1, 58-64.

Binotti, F. F. S., Arf, O., Cardoso, E. D., Sá, M. E., Buzetti, S., \& Nascimento, V. (2010). Fontes e doses de nitrogênio em cobertura no feijoeiro de inverno irrigado no sistema plantio direto. Bioscience Journal, 26, $770-778$.

Biscaro, G. A., Freitas Junior, N. A., Soratto, R. P., Kikuti, H., Goulart Junior, S. A. R., \& Aguirre, W. (2012). Nitrogênio em cobertura e molibdênio via foliar no feijoeiro irrigado cultivado em solo de cerrado. Acta Scientiarum Agronomy, 33, 665-670. https://doi.org/10.4025/actasciagron.v33i4.6387

Cardoso, S. M. (2011). Fontes e doses de nitrogênio na nutrição, produção e qualidade do feijoeiro (Master's thesis, Universidade Estadual Paulista, São Paulo, Brasil). Retrieved from https://repositorio.unesp.br/ handle/11449/86361

Chiorato, A. F., Carbonell, S. A. M., Carvalho, C. R. L., Barros, V. L. N. P., Borges, W. L. B., Ticelli, M., ... Santos, N. C. B. (2012). 'IAC Imperador': Early maturity "carioca” bean cultivar. Crop Breeding and Applied Biotechnology, 12, 297-300. https://doi.org/10.1590/S1984-70332012000400012

CONAB (Companhia Nacional de Abastecimento). (2009). Acompanhamento da safra brasileira de grãos. Retrieved September 30, 2017, from http:/www.conab.gov.br

Crusciol, C. A. C., Soratto, R. P., Silva, L. M., \& Lemos, L. B. (2007). Fontes e doses de nitrogênio para o feijoeiro em sucessão a gramíneas no sistema plantio direto. Revista Brasileira de Ciência do Solo, 31, 1545-1552. https://doi.org/10.1590/S0100-06832007000600031

Cunha, P. C. R., Silveira, P. M., Ximenes, P. A., Sousa, R. F., Alves Júnior, J., \& Nascimento, J. L. (2013). Fontes, formas de aplicação e doses de nitrogênio em feijoeiro irrigado sob plantio direto. Pesquisa Agropecuária Tropical, 41, 80-86. https://doi.org/10.5216/pat.v41i1.7515

Epstein, E., \& Bloom, A. J. (2006). Nutrição mineral de plantas: princípios e perspectivas. Londrina, PR: Editora Planta.

FAO (Food and Agriculture Organization of the United Nations). (2017). Production: Crops. Retrieved July 8, 2017, from http:/www.fao.org/faostat/es/\#data/QC/visualize

Ferraz, R. L. S., Melo, A. S., Suassuna, J. F., Brito, M. E. B., Fernandes, P. D., \& Nunes Júnior, E. S. (2012). Gas exchange and photosynthetic efficiency in common bean ecotypes grown in a semiarid environment. Pesquisa Agropecuária Tropical, 42, 181-188. https://doi.org/10.1590/S1983-40632012000200010

Flôres, J. A., Amaral, C. B., Pinto, C. C., Mingotte, F. L. C., Lemos, L. B., \& Fornasieri Filho, D. (2014). Parcelamento do nitrogênio no desempenho agronômico do feijoeiro-comum em plantio direto. Paper presented at the Congresso Nacional de Pesquisa de Feijão, Londrina, PR, Brazil. Retrieved from https://www.bdpa.cnptia.embrapa.br

IBGE (Instituto Brasileiro de Geografia e Estatística). (2017). Levantamento Sistemático da Produção Agrícola. Retrieved July 14, 2017, from http://www.ibge.gov.br 
Jaimez, R. E., Rada, F., García-Núñez, C., \& Azócar, A. A. (2005). Seasonal variations in leaf gas exchange of platain cv. 'Hartón' (Musa AAB) under different soil water conditions in a humid tropical region. Scientia Horticulturae, 104, 79-89. https://doi.org/10.1016/j.scienta.2004.07.002

Konrad, M. L. F., Silva, J. A. B., Furlani, P. R., \& Machado, E. C. (2005). Trocas gasosas e fluorescência da clorofila em seis cultivares de cafeeiro sob estresse de alumínio. Bragantia, 64, 339-347. https://doi.org/ 10.1590/S0006-87052005000300004

Kurtz, C., Ernani, P. R., Meirelles, C. J. L., \& Petry, E. (2012). Rendimento e conservação de cebola alterados pela dose e parcelamento de nitrogênio em cobertura. Revista Brasileira de Ciência do Solo, 36, 865-875. https://doi.org/10.1590/S0100-06832012000300017

Larcher, W. (2004). Ecofisiologia vegetal. São Carlos, SP: RiMa.

Machado, E. C., Schmidt, P. T., Medina, C. L., \& Ribeiro, R. V. (2005). Respostas da fotossíntese de três espécies de citros a fatores ambientais. Pesquisa Agropecuária Brasileira, 40, 1161-1170. https://doi.org/ 10.1590/S0100-204X2005001200002

Marschner, H. (1995). Mineral nutrition of higher plant (2nd ed.). New York, NY: Ac. Press.

Mendes, F. F., Ramalho, M. A. P., \& Abreu, A. F. B. (2009). Índice de seleção para escolha de populações segregantes de feijoeiro-comum. Pesquisa Agropecuária Brasileira, 44, 1312-1318. https://doi.org/10.1590/ S0100-204X2009001000015

Moreira, J. A. A., Stone, L. F., \& Biava, M. (2003). Feijão: o produtor pergunta, a Embrapa responde. Brasília, DF: Embrapa Informação Tecnológica.

Nakayama, F. T., Pinheiro, G. A. S., \& Zerbini, E. F. (2013). Eficiência do fertilizante organomineral na produtividade do feijoeiro (Phaseolus vulgaris L.) em sistema de semeadura direta. Fórum Ambiental da Alta Paulista, 9, 122-138. https://doi.org/10.17271/19800827972013551

Nascente, A. S., Kluthcouski, J., Crusciol, C. A. C., Cobucci, T., \& Oliveira, P. (2012). Fertilization of common bean cultivars in tropical lowlands. Pesquisa Agropecuária Tropical, 42, 407-415. https://doi.org/10.1590/ S1983-40632012000400003

Oliveira, C. O., Sá, M. E., Bossolani, J. W., Garcia, A., \& Merloti, L. F. (2014). Análise econômica de feijão com diferentes plantas de cobertura e adubação nitrogenada em cobertura. Paper presented at the Congresso Nacional de Pesquisa de Feijão, Londrina, PR, Brazil. Retrieved from https://www.bdpa.cnptia.embrapa.br

Paiva, A. S., Fernandes, E. J., Rodrigues, T. J. D., \& Turco, J. E. P. (2005). Condutância estomática em folhas de feijoeiro submetido a diferentes regimes de irrigação. Engenharia Agrícola, 25(1), 161-169. https://doi.org/ 10.1590/S0100-69162005000100018

Peel, M. C., Finlayson, B. L., \& Mcmahon, T. A. (2007). Updated world map of the Köppen-Geiger climate classification. Hydrology and Earth System Sciences, 4, 439-473. https://doi.org/10.5194/hess-111633-2007

Portes, T. A. (1996). Ecofisiologia. In R. S. Araújo, C. A. Rava, L. F. Stone, \& M. J. O. Zimmermann (Eds.), Cultura do feijoeiro comum no Brasil (pp. 101-138). Piracicaba, SP: Potafós.

Rodriguez, M., Rau, D., Bitocchi, E., Bellucci, E., Biagetti, E., Carboni, A., ... Attene, G. (2016). Landscape genetics, adaptive diversity and population structure in Phaseolus vulgaris. New Phytologist Journal, 209, 1781-1794. https://doi.org/10.1111/nph.13713

Salgado, F. H. M., Silva, J., Oliveira, T. C., Tonello, L. P. T., Passos, N. G. P., \& Fidelis, R. R. (2012). Efeito do nitrogênio em feijão cultivado em terras altas no sul do estado de Tocantins. Ambiência, 8, 125-136. https://doi.org/10.5777/ambiencia.2012.01.10

Silva, F. L. B., Lacerda, C. F., Neves, A. L. R., Sousa, G. G., Sousa, C. H. C., \& Ferreira, F. J. (2013). Irrigação com águas salinas e uso de biofertilizante bovino nas trocas gasosas e produtividade de feijão-caupi. Irriga, 18, 304-317. https://doi.org/10.15809/irriga.2013v18n2p304

Soares, B. L., Ferreira, P. A. A., Rufini, M., Martins, F. A. D., Oliveira, D. P., Reis, R. P., ... Moreira, F. M. S. (2016). Agronomic and economic efficiency of common-bean inoculation with rhizobia and mineral nitrogen fertilization. Revista Brasileira de Ciência do Solo, 40, 1-13. https://doi.org/10.1590/18069657 rbcs 20150235 
Soares, L. A., Furtado, G. F., Andrade, E. M. G., Sousa, J. R. M., Guerra, H. O. C., \& Nascimento, R. D. (2013). Troca de $\mathrm{CO}_{2}$ do feijão-caupi irrigado com água salina e fertilização nitrogenada. Agropecuária Científica no Semiárido, 9, 30-37.

Soratto, R. P., Carvalho, M. A. C., \& Arf, O. (2006). Nitrogênio em cobertura no feijoeiro cultivado em plantio direto. Revista Brasileira de Ciência do Solo, 30, 259-265. https://doi.org/10.1590/S0100-0683200600 0200007

Sousa, J. R. M., Andrade, E. M. G., Furtado, G. F., Soares, L. A. A. S., Silva, S. S., \& Sousa Júnior, J. R. (2013). Crescimento vegetativo do feijão caupi sob doses de nitrogênio irrigado com águas salinas. Agropecuária Cientifica no Semiárido, 9, 94-98.

Sousa, S. A., Silva, J., Venâncio, J. L., Oliveira, T. C. O., Barro, H. B., \& Fidelis, R. R. (2012). Efeito do nitrogênio em genótipos de feijão cultivados em várzea úmida irrigada do Estado do Tocantins. Journal Biotecnology Biodiversity, 3, 80-88.

Suassuna, J. F., Melo, A. S., Sousa, M. S. S., Costa, F. S., Fernandes, P. D., Pereira, V. M., \& Brito, M. E. B. (2010). Desenvolvimento e eficiência fotoquímica em mudas de híbrido de maracujazeiro sob lâminas de água. Bioscience Journal, 26, 566-571.

Taiz, L., Zeiger, E., Moller, I. M., \& Murphy, A. (2017). Fisiologia e desenvolvimento vegetal (6th ed.). Porto Alegre, RS: Artmed.

Tatagiba, S. D., Moraes, G. A. B. K., Nascimento, K. J. T., \& Peloso, A. F. (2014). Limitações fotossintéticas em folhas de plantas de tomateiro submetidas a crescentes concentrações salinas. Revista Engenharia na Agricultura, 22, 138-149. https://doi.org/10.13083/reveng.v22i2.488

Trethewey, J. A. K., Rolston, M. P., Mccloy, B. L., \& Chynoweth, R. J. (2016). The plant growth regulator trinexapac-ethyl, increases seed yield in annual ryegrass (Lolium multiflorum Lam.). Agricultural Research, 59, 113-121. https://doi.org/10.1080/00288233.2015.1134590

Urchei, M. A., Rodrigues, J. D., \& Stone, L. F. (2000). Análise de crescimento de duas cultivares de feijoeiro sob irrigação, em plantio direto e preparo convencional. Pesquisa Agropecuária Brasileira, 35, 497-506. https://doi.org/10.1590/S0100-204X2000000300004

Valderrama, M., Buzetti, S., Benett, C. G. S., Andreotti, M., Arf, O., \& Sá, M. E. (2012). Fontes e doses de nitrogênio e fósforo em feijoeiro no sistema plantio direto. Pesquisa Agropecuária Tropical, 39, 191-196.

Vleugelsa, T., Rijckaert, G., \& Gislum, R. (2017). Seed yield response to N fertilization and potential of proximal sensing in Italian ryegrass seed crops. Field Crops Research, 211, 37-47. https://doi.org/10.1016/ j.fcr.2017.06.018

Yuan, M., Ruark, M. D., \& Bland, W. L. (2017). A simple model for snap bean (Phaseolus vulgaris L.) development, growth and yield in response to nitrogen. Field Crops Research, 211, 125-136. https://doi.org/ 10.1016/j.fcr.2017.06.014

Zanandrea, I., Nassi, F. L., Turchetto, A. C., Braga, E. J. B., Peters, J. A., \& Bacari, M. A. (2006). Efeito da salinidade sob parâmetros de fluorescência em Phaseolus vulgaris. Revista Brasileira Agrociência, 12, 157-161. https://doi.org/10.18539/cast.v12i2.4512

\section{Copyrights}

Copyright for this article is retained by the author(s), with first publication rights granted to the journal.

This is an open-access article distributed under the terms and conditions of the Creative Commons Attribution license (http://creativecommons.org/licenses/by/4.0/). 